TRAMES, 2021, 25(75/70), 4, 421-435

\title{
CIRCASSIANS IN RUSSIA AND TURKEY: DIVIDED ETHNIC GROUP FROM SELF-CONSCIOUSNESS TO CONSOLIDATION
}

\author{
Tatiana N. Litvinova and David G. Bdoyan \\ Moscow State Institute of International Relations
}

\begin{abstract}
The article considers the phenomenon of divided ethnic groups and their political consolidation across the state borders on the example of Circassians in Turkey and Russia. The reason for the Circassian division was a series of refugee waves from the Russian Empire in the mid-nineteenth century. The Turkish Circassian diaspora is the largest outside the homeland accounting for about 2.5 million people. Those Circassians who stayed in the North Caucasus (about 700 000), mostly inhabit four subjects of the Russian Federation. The parts of divided Circassians in Russia and Turkey with their organizations make attempts for consolidation and cultural cooperation through state boundaries, which have legal, cultural, informational and international consequences. While the Russian Circassian organizations are currently showing a more loyal attitude towards the federal center, the mobilization of KAFFED and Turkish Circassians in general is intensifying both in international issues and in the internal political struggle in Turkey.
\end{abstract}

Keywords: Circassians, Caucasian War, Russia, Turkey, ethnic organizations, divided ethnic group, diaspora, consolidation

DOI: https//doi.org/10.3176/tr.2021.4.03

Received 12 July 2021, accepted 17 August 2021, printed and available online 10 December 2021 


\section{Introduction}

The majority of states in the modern world are multiethnic because they incorporate more than one ethnic group. Furthermore, the state borders were established without taking into account historic territories and boundaries of the ethnic habitats. So many ethnic groups in the world such as Kurds, Basques, Lezgins, and others spread outside state borders. On the other hand, ethnic diaspora communities are found in foreign countries due to migration of the population. Both these cases - non-ethnic state borders and migration - result in divided societies.

An ethnic group is usually inclined to form and articulate its identity and sometimes to declare a self-determination program. That is why the problem of divided ethnic groups takes on considerable significance in national politics and foreign affairs. Political processes in nation states often encounter the politicization of particularistic group identities based on ethnic, religious, cultural and social differences in society. The danger of the ethno-cultural component erosion forces some ethnic groups to actively form elements of self-consciousness that would help them stand up against culture and lifestyle unification that nation building presents. The consolidation of an ethnic group split among different states can become an instrument and a path to cultural and ethnic revival.

This investigation has the focus on ethnic diaspora and minorities of Circassians of the North Caucasus found in different states and geographical areas. Circassians (Adyghe) is a common name for several related ethnic groups living in Russia and those who have dispersed far from their homeland mostly to Middle East countries, including Turkey. Their history and social activity at present became the subject of research after the collapse of the USSR. One of the latest books devoted to this people written by Adel Bashqawi (2019) depicted Circassians as an ethnic group, which preserved their identity "for the duration of both tyrant tsarist imperial and Soviet/Communist eras" and only in the 1990s "started to become enlightened with information". How far can ethnic self-consciousness and mobilization advance Circassians in the wake of cultural resurgence? Marat Grebennikov (2015) considers that Circassians' mobilization in Russia can hardly be stopped, and this fact being ignored by Moscow can have far-reaching consequences. On the contrary, Sufian Zhemukhov (2008) argues that "Russia's attitude toward the Circassian world has been generally positive and helpful". Veronika Tsibenko and Sergey Tsibenko (2015) studied the historical background on the transformation of the Circassian question and concluded that a sharp increase in the interest in Circassian problem after 2007 was conditioned not only by internal processes of Circassian national movement mobilization, but by foreign policy factors and international perception as well. Different authors turned to examining the politicization of Circassians historical memory after the Olympic Games in Sochi 2014 (Uznarodov 2016, Akkieva and Kocev 2016) when ethnic resurgence started to be used as a factor of politicization.

The Circassian diaspora in Turkey is often regarded as part of North Caucasian people (Gafarli 2014), the descendants of immigrants from the Russian-Turkish wars period of the 19th century, whose political activity depends on Turkish relations 
with Russia and Georgia. The Circassian ethnic mobilization that began in the late 1980s due to the fall of the Iron Curtain and the revival of close ties of Russian Circassians with the diaspora in Turkey "heralded a new chapter in the actualization of the Circassian question on the international arena" (Tsibenko 2016: 441).

The article covers several questions: the causes of division among Circassians; the level of communication between Circassians' organizations in Turkey and back in their homeland; the political projects and experience of ethnic recovery and political consolidation. As research methods, the authors used content analysis of program documents, resolutions, and news publications from the websites of Circassian organizations, as well as the media monitoring.

\section{Theoretical approaches and methodology}

The theory of divided ethnic groups is still not developed enough. However, rich conceptual basis can be found in theories of ethnic identity and ethnic mobilization.

In the study of ethnic politics Milton Esman (1994: 6) names two types of ethnic groups: 'homeland societies and immigrant diasporas'. In case an ethnic group represented by homeland society and diaspora abroad the main methodological question is what criteria define them as still the same ethnos. Anthony Smith (1993: 5051), the representative of primordial approach, gives six reasons for ethnic identity: 1) ethnonym; 2) faith in the common origin; 3) historical memory; 4) culture; 5) territory; 6) a sense of solidarity. Primordialism recognizes the natural strength of ethnic identity passed from generation to generation and caused by the sense of consanguinity and origin which can survive the fact of territorial division.

Unlike the primordial concept the constructivist theory suggests that a nation state blurs ethnocultural differences by the very fact of its existence (common schools, army, legal regulations, economic practices) and the policy targeted at defending the national principle of matching the state and its cultural borders (Gellner 1983). Thus, ethnic self-consciousness depends not so much on the language, religion or common culture, but on the shared history and solidarity around common symbols. This can explain why diasporas who have lived in an alien community for decades and centuries can forget the language but remember the origin and feel in touch with their motherland.

Brendan O'Leary (2007: 886) made an essential contribution to the development of the divided people theory. He interpreted the externally determined division of an ethnically homogeneous group (Kurdistan) as a negative phenomenon, but the internally determined division of parts of a nationally or ethnically heterogeneous formation (Austro-Hungarian Empire) as less dramatic and even positive.

The political mobilization and attempts to consolidate a divided ethnic group depend on whether the parts of ethnic entities are under oppression or discrimination. According to William Safran (1991: 83-84), diasporas are communities of emigrants, dispersed from their place of origin, who preserve the historical memory about their homeland; who consider their country of origin a place of possible return; 
who are trying to preserve and restore their homeland, and who regard their group consciousness and solidarity as quite important. Diasporas/or minorities in a multiethnic state usually demand "nondiscriminatory participation as individuals in public affairs" with equal access to education, employment, public services as well with the opportunity "to maintain institutions that perpetuate elements of their inherited culture" (Esman 1994: 9).

There can be two theoretical models of divided ethnic groups' political activity observed. The universalist dimension views a diaspora as the group constituting a post-national identity. Modern diasporic communities exemplify a growing stream of the so-called 'globalization from below' (Brecher 1993: 123). In this case the cultural contacts between parts of divided nation and their political activity are not converted into struggle for self-determination.

On the other hand, the particularistic approach presents the model of ethnic group /or diasporic nationalism. James Clifford (1994: 307) emphasizes the difficulties of assimilation of the groups "that maintain important allegiances and practical connections to their homeland or dispersed community" of the same origin. Thus, those minority groups who cannot be merged with a national system create a political program of recovery and consolidation, which sometimes contradicts the territorial integrity principle and conflicts with host state authorities.

\section{Causes of division and ethnic resurgence of Circassians}

The Russian Empire colonization of the North Caucasus during and after the Caucasian War (1817-1864) led to the expulsion of Circassians and other indigenous groups. These lands were assigned to Cossacks and Russians. The eventual result of the Russian success in the region was a "series of refugee waves in the third quarter of the XIX century, by boats, carts and on foot, from the North Caucasus to the Ottoman Empire" (Kaya 2005: 217-218). Thus, nowadays almost all ethnic groups living in the North Caucasus have their own diasporas in Turkey, which make up a significant part of the population and influence political decision-making.

The Circassian diaspora is scattered across the Balkans, Anatolia, Syria, Jordan, Israel, Germany, USA, Holland. However, the Turkish Diaspora of the Circassians is the most numerous.

\subsection{Resurgence of Circassian diaspora in Turkey}

The Circassians who left the Russian Empire considered Istanbul, which was then the center of the Muslim world, to be the safest place to seek refuge. Apart from Istanbul, the Circassians in the Ottoman Empire settled in the areas of Adapazari, Balikesir, Bursa, Canakkale, Duzce, Izmit, and some part of them in Amasya, Adana, Çorum, Samsun, Sivas, Tokat, Yozgat, Kayseri, Maraş, and Hatay (Alankuş 2009: 3). The number of refugees is a matter of contention with figures ranging from 500000 to 2 million. Although there are not official statistics, approximately 2-2.5 million of Circassians are said to reside in Turkey (Kaya 2005: 217-218). The calculation of the 
exact number of Circassians in Turkey is complicated due to the lack of an accurate definition of who a Circassian is. Thus, official censuses cannot show exact numbers based on self-identification. For a long historical period, the Ottoman Empire was a 'melting pot' for many peoples (Caya 2015: 299), and the Circassians found it easy to assimilate due to the religion they shared.

The difficulties faced by the settlers from the North Caucasus in the Ottoman Empire are set forth in the appeal of the Circassian nobility to the Porte of 1872, published by Georgij Čočiev. Expressing gratitude to Porte for the generous allocation of financial and material resources for immigrant Caucasians, the authors of the document noted that a significant part of these funds had been stolen by corrupt officials. Attention was also drawn to numerous cases of non-provision of agricultural implements, livestock, money for housing construction to immigrants (Č́očiev 2013: 125).

The question of Circassian identity has not been manifested since the foundation of the national Turkish Republic. At the Conference of Lausanne (November 1922July 1923) Lord Curzon proposed to consider the Circassians one of the national minorities, but the chief negotiator of the Turkish delegation İsmet İnönü noted: "The Circassians are our brothers. We cannot see them separately from us as Christians and Jews, we cannot separate them" (Güsar 1975: 24-25). The Turkish authorities have been conducting the assimilation policy to "create a monolithic Turkish nation for a long time" (Tsibenko and Tsibenko 2015: 453).

The Caucasian Culture Association, founded in 1953 in Istanbul, was the first organization to represent the peoples of the North Caucasus in Turkey. It was mainly engaged in anti-Soviet propaganda. In the 1960s and 1970s, Caucasian organizations began to spread to almost all major cities. Their leaders, who were mostly welleducated people began to look for ways to preserve their identity. Some of them sought to gain greater cultural and linguistic freedom from the Turkish government, but many believed that the revival of the ethnic group is possible only after returning to their historical homeland.

As a result of a military coup in Turkey, led by General Kenan Evren, the year 1980 saw the parliament be dissolved and the activities of political parties and public organizations be banned. The ban also applied to organizations of the Circassian diaspora, and some of their leaders ended up in prisons. Circassian organizations resumed their activities in 1984 (Alankuş 2009: 3).

The ethnic resurgence within the Circassian diaspora in Turkey started about thirty years ago, right after the end of the Cold War. According to Mustafa Oral (2008), a crucial factor to preserve the Circassian identity in Turkey was comprehensive Circassian History which was written in 1882 in line with the traditional Ottoman historiography and has an ummah-nationalist nature. Aysenur Dogan (2019), in his turn, notes the importance of newspapers published by the Circassians in Turkey to preserve the language and maintain contacts with the Circassian communities of the Caucasus.

According to Orkhan Gafarli (2014), the main reasons for this increased social activity of Turkish Circassians were secession conflicts in Georgia and in Russia, 
which resulted in Circassians Associations becoming more noticeable in the media. Thus, the collapse of the Soviet Union and the increasing contacts with the historical homeland led to a rise in the diaspora's self-consciousness. The organization of the Circassians in Turkey began to actively lobby their interests both domestically and in the post-Soviet space.

Ethnic resurgence of Circassians in Turkey resulted in the growing activity of public associations which play an instrumental role in the processes of establishing and articulating the Circassian diaspora's identity. Now there are about 80 active Circassian associations in Turkey, located in the regions with a significant proportion of Circassians, most of which united behind the Federation of the Caucasian Associations (KAFFED) in 2003.

Forming its own political Party of Pluralistic Democracy in 2014 was an important factor in the ethnopolitical mobilization of the Circassians in Turkey. Although according to the Turkish legislation the name of the party cannot refer to ethnicity, the party was created by Circassian public movements (Hansen 2012). In June 2015 it nominated nine independent candidates for parliamentary elections, who could not get a seat due to lack of broad support among the Circassians themselves. Despite the failure of the first Circassian political party, the general politicization of the diaspora in Turkey continues to grow (Cibenko 2019: 61).

Considering the conflict between Turkish 'citizenship' and the strong Circassians community identity, Eylem Akdeniz Goker (2018) notes that the sense of belonging to a diaspora does not undermine the diasporic communities' citizenship status within the host countries, on the contrary, it strengthens a process of active citizenship.

\subsection{Mobilization of Circassians in Russia}

Those Circassians who stayed in Russia (their number is estimated at 700 000) now live in four subjects of the Russian Federation: the Kabardino-Balkar Republic, the Karachay-Cherkess Republic, the Republic of Adygea and Krasnodar Krai.

The ethnic resurgence of Circassians in Russia and calls for the creation of a sovereign Circassian Republic have been heard since the early 1990s. Naturally, the collapse of the USSR and the 'parade of sovereignties' served as the biggest impulse for this. Consequently, Kabardino-Balkaria, Adygea and Karachay-Cherkessia rose in their status from autonomies to the subjects (republics) of the Russian Federation each with a president, the government, the legislative institution, the constitution and the official status accorded to their native languages. The parliament of the Republic of Adygea was named State Council Khase ('Khase' in the old Circassian style) in accordance with tradition and historic memory, and the official flag of the republic was the old Circassian flag with twelve stars and three crossed arrows on a green background (Zhemukhov 2008: 4).

After gaining a serious political status within the Russian Federation, Circassians began to consolidate the territories inhabited by related ethnic groups. The requirement for the creation of 'Great Circassia' was first declared at the II Congress of Shapsugian people, held from 30 October to 1 November 1991. The main issue of the 'Great Circassia' project was to bring the territories of Adygea, Kabardino-Balkaria, 
Karachay-Cherkessia, Sochi and Anapa to the fold, as well as the establishment of the Circassian government. In 1992 Adygea, Kabardino-Balkaria and KarachayCherkessia signed the Friendship and Partnership Agreement, and in 1997 the InterParliamentary Council of the three republics was created.

Circassian organizations began to openly talk about their ultimate and main goal, which was the creation of an independent Circassian state in wide territories. Thus, the same period saw the Circassian ethnic movement declare the sovereign Circassian Republic, though it has not been recognized by the Russian authorities. In autumn 1992 Circassian organizations of Kabardino-Balkaria 'Adyghe Khase' and 'Congress of Kabardian people' stated their intention to secede from Russia and establish an independent state. But the President of the Republic of KabardinoBalkaria Valery Kokov actively suppressed the secessionist movement (Uznarodov 2016: 61).

One of the most influential organizations of Circassians in Russia is "Adyghe Khase'. However, the International Circassian Association (ICA), the Charter (International Circassian Association 1991) of which was adopted at the founding congress in May 1991, is the most active now. Now the ICA is represented not only in Russia, but in Abkhazia, Turkey, Jordan, Syria, Israel, the EU and the USA through its member organizations.

The growth of the Circassians' ethnic identity was manifested during the AllRussia Population Census of 2002. The legislation granted citizens the right to indicate their ethnicity relying on self-identification in the census form. Before the census the 'Adyghe Khase' leaders appealed to representatives of four related ethnic groups (Adyghe, Kabardians, Circassians, Adyghe-Shapsugs) to indicate a common for them self-name 'Adyghe' in the column 'Ethnicity'. According to the leaders of the organization, this was necessary for the consolidation, and they considered that the ethnonym Adyghe most accurately reflects the nationality of 'ethno-cultural society' (Soveckaja Adygeja 2002). This idea emphasizes their ambition to build a sovereign nation state.

Similar appeals were heard on the eve of the last All-Russian population census of 2010. In July 2009, leaflets were stuck to the monument 'Forever with Russia' in the capital of Kabardino-Balkaria, Nalchik. They said: "During the 2010 census, which will be conducted in Russia, we urge you, brothers and sisters, to indicate your nationality as 'Circassian' to census-takers" (REGNUM 2009). This interesting and ambiguous function of census to serve as an instrument of nation-building was considered by Irina Krasnopol'skaja and Galina Solodova (2016). They wrote that census helped ethnic groups to form the shapes and borders of their identity.

Ethnic Circassians (Kabardians) make up the majority (57.2\%) in only one subject of the Russian Federation, which is Kabardino-Balkaria, out of four territories of their compact residence. As for Karachay-Cherkessia and the Republic of Adygea, Circassians are a minority with the total population of $11.9 \%$ and $25.8 \%$ respectively, while in Krasnodar Krai they make up about $0.4 \%$ of population (Vserossijskaja perepis' 2010). The areas of compact residence of the Adyghe currently do not border each other, which makes impossible to implement the idea of a single subject within 
the Russian Federation. However, there are no obstacles for ethnocultural interaction with related diasporas beyond the state borders.

Thus, the ethnic revival of the Circassians living in Russia and Turkey began at about the same time at the turn of 1980-1990. The growing self-awareness led to active institutionalization of the ethnic movement, which pursued such goals as consolidation, repatriation to the historic land and political self-determination.

\section{Consolidation of divided Caucasian ethnic groups: political projects and experience}

One of the most critical and painful problems concerning Circassians in the whole world is the recognition of their genocide. According to the "Convention on the Prevention and Punishment of the Crime of Genocide" adopted by the UN General Assembly on 9 December 1948, genocide is understood as "acts committed with the intent to destroy, in whole or in part, a national, ethnical, racial or religious group". Though at the end of the Caucasian War the Russian Imperial Army drove Circassians from the plains to the mountains, Tsarist Russia had none of the intentions listed in the Convention. Nevertheless, the issue of 'Circassian genocide' became part of the ethnic politicization. In October 2006 Circassian public organizations sent the request for recognition of the genocide against Circassian people within and after the Caucasian war (1816-1864) to the president of the European parliament Joseph Borrell Fontelles.

The organization KAFFED in Turkey proclaimed 21 May the Day of Remembrance to mark one of the worst human sufferings in the history. Since the first day of its establishment in 2003, KAFFED has organized scientific meetings, published academic studies, become active for the recognition of the Circassian genocide at the international fora. KAFFED has created a special Internet site of the 21 May with the aim (Federation of Caucasian Associations 2020) to provide information about the Circassian genocide.

The claims for recognition of genocides can be viewed as a political request to recognize Circassians (Adyghes) as nation having a potential to rejoin and organize its own statehood.

Sufian Zhemukhov (2012: 511) conceptualized the map of Circassian national movement in Russia and divided it into five wings:

Nationalists who initiated the promotion of Circassian question on the international agenda;

- $\quad$ Sovereigntists who protected the idea of sovereign Republic of Adygeya during and after the 'parade of sovereignties' in Russia;

- Centrists who want to establish a common ground to unify the international Circassian movement;

- Culturalists who protect the primordial lands and interests of Kabardians, Circassians and Adyghes in Russia; 
- Accommodationists who tried to combine the protecting of primordial rights and support the Kremlin policy in the North Caucasus.

The problems of recognition of genocide and repatriation of compatriots to the historic homeland were widely discussed at the International Circassian Congresses.

The 8th Congress in October 2009 lodged two appeals to the President of the Russian Federation, Medvedev (2008-2012). The first appeal advocated the protection of national cultural monuments and historical heritage of the Adyghes, which are endangered due to sports facilities being built in the vicinity of Sochi. The second appeal contained a request to give representatives of the Circassian diaspora abroad the legal status of compatriots, which could facilitate the process of repatriation (International Circassian Association 2009).

Choosing Sochi, with Krasnaya Polyana (where Russian troops held a parade to honor the end of the Caucasian War on May 21, 1864) being the main area, as the place for 2014 Winter Olympics was a sensitive issue. The protests of Circassians organizations in Turkey grew into 'No Sochi 2014' campaign and on 15 February 2014 Circassian diaspora held protests in front of the Russian Consulate General in Istanbul (Gafarli 2014: 181).

To reduce the protest mood a representative of Circassians was included as a member of the Krasnodar Krai administration. In November 2013 Mugdin Chermit, the vice-president of the International Circassian Association, was appointed the deputy head of the Department of Internal Policy. His task was to form a positive perception of the Sochi Olympics by the Circassian international community (Bredixin 2019: 33). For example, the central stadium of the Winter Olympic Games in Sochi was named 'Fisht' ('white rime' in the Adyghe language). According to Uznarodov (2019), despite a certain 'revival' of the Circassian issue in Russia between 2007 and 2014, after a surge in activity during the 2014 Olympics it is definitely on the decline. The organized Circassian movement is currently characterized by political loyalty to the Russian state.

Another important issue, which has been repeatedly raised by the international Circassian movement, is the repatriation of ethnic Circassians to their historical homeland. The main obstacle is an almost complete assimilation in the new homeland, the lack of knowledge of the language and culture. During the last 20 years only about three thousand people return to their historical homeland from abroad.

One of the urgent issues of recent years concerning Circassians in Russia and all over the world is refugees from Syria. Both International Circassians Association in Russia and KAFFED in Turkey are seriously disturbed by this. Starting from December 2011 refugees from Syria started arriving in Kabardino-Balkaria. Fiftytwo households with personal plots of land were purchased in 2014 for them. At the same time, since the beginning of 2014 the Federal Migration Service of the Republic of Adygea has denied more than 150 applications for citizenship and refugee status for Circassians from Syria without explaining the reason. In its turn, Karachay-Cherkessia provided help to only thirty out of one hundred repatriates, who applied for help in processing documents and refugee status and placement.

According to declaration of Yaşar Aslankaya, chairman of KAFFED, more than 
two million Syrian refugees came in Turkey, about three thousands of them were Circassians. All compatriots were accommodated in different places of the Circassian compact settlements (International Circassian Association 2014).

After the Russian Su-24 shootdown incident Russian-Turkish relations suffered a severe crisis. It is important to mention that on 8 December 2015 the delegation of KAFFED in Turkey, led by President Aslankaya, met the Russian Ambassador in Turkey, A. G. Karlov. The KAFFED delegation expressed their concerns about the negative effect of the Russian-Turkish crisis on the relationships that Circassians have with their homeland, specifically regarding the position of repatriates, the new visa regime to be started on 1 January, the withdrawal of professors teaching Circassian courses at Duzce University. Karlov mentioned that he shared those concerns, but the Russian government had to take precautionary measures after the shutdown of the Russian plane. It was agreed that measures to mitigate the negative effects of the crisis should be taken (KAFFED 2015).

As for the Circassian organizations in Russia, they showed support to President Putin's political position during several months of the Russian-Turkish crisis. However, in September 2016 Aslankaya participated in the XI extraordinary Congress of the ICA in Nalchik. When leaving Russia, he was detained, and it was announced to him that he was banned from entering Russia until 2020.

At the end of 2016, the ICA, which for more than two decades was the most respected Circassian organization, saw a split due to the fact that the Federation of Caucasian Associations in Turkey (KAFFED) decided to suspend its membership in the International Circassian Association. As noted by ICA representatives themselves, this may be due to both the ban on entry into Russia of the KAFFED chairman Aslankaya in September 2016 and the pro-Russian position of the ICA (Akkieva and Kocev 2016).

On 30 June 2018 a regular meeting of the Council of the International Circassian Association (ICA) was held in Ankara. The issues, discussed at the Council, concerned the activities of the KAFFED, the situation of the Circassians in Syria and measures to help compatriots staying in Russia, studying Circassian youth in Russian universities, the development of the Circassian language, organizing the XII ICA Congress, the adoption of new Adyghe public organizations in the ICA, and others.

Mass events to commemorate the 155th Day of Remembrance for the victims of the Caucasian War were held on 21 May 2019, both in Russia and Turkey. According to the 'Caucasian Knot', Istanbul authorities banned a mourning procession to the walls of the Russian Consulate General (Tuayev 2019). Thus, we agree with Veronika Tsibenko, that the high level of politicization of Turkish Circassians can "have a negative impact on the Russian-Turkish relations" (Tsibenko 2016: 457).

A commemorative event in Nalchik on the same day brought together about 3,000 people. The head of the ICA H. Sokhrokov proclaimed in his speech: "The memory of this war continues to live in the minds of our people. (...) nine out of ten Adygs practically died or were expelled from their native land. (...) If only about 700 thousand Circassians now live in the Russian Federation, there are more than six 
million ethnic Circassians, remembering the tragedy of their people in the world, in different countries and continents" (Maratova 2019).

The annual activity on the Remembrance Day could not be stopped even with the pandemic of COVID-19 though most meetings and conferences were organized online. The ICA published videoconferences, the speeches of the head of the Kabardino-Balkar Republic K. V. Kokov and the head of the ICA H. Sokhrokov on the occasion of the Caucasian War's 156th anniversary. Furthermore, during lockdowns under special concern were the repatriates from Syria as they had no income. The ICA held a charity event for compatriots (140 families) who moved to Kabardino-Balkaria (International Circassian Association 2020).

On April 25, 2021, the Day of the Circassian Flag, several festive events were held in Adygea, Kabardino-Balkaria and Karachay-Cherkessia. On May 21, a traditional procession dedicated to the Day of Remembrance was held in Nalchik, but in Maikop, due to coronavirus restrictions, the event was canceled. Some Circassian activists were against the cancellation of mass events on the Day of Remembrance and Sorrow (Gricevič 2021).

In early July 2021, after a regular meeting of the International Circassian Association, KAFFED Chairman Yıldız Şekerci and the accompanying delegation took part in the meeting in the Republic of Kabardino-Balkaria with ICA President Hauti Sokhrokov. Şekerci emphasized that the ICA should be considered as a representative of the Circassians in the world, which should become the emerging problems solving center (KAFFED 2021).

The example of Circassians shows us that the consolidation of divided ethnic groups is becoming one of the features of the globalization era.

\section{Conclusion}

Thus, the historical memory of the Circassians carefully preserves the stories of the struggle and defeat in the Caucasian War and has a serious potential for politicization in order to consolidate the Circassians living in different countries. This aspect should be taken into account in the modern domestic national policy of Russia, as well as in the foreign policy of the Russian Federation towards countries with significant Circassian diasporas, primarily Turkey.

The ICA and KAFFED have become institutionalized entities of consolidating ethnic groups that put forward political demands: recognition of the genocide of the Circassians; the return of compatriots living abroad; the consolidation of the Circassians of Russia (registering them as one ethnic group in the census); protection of monuments of ethnic culture. According to political activity of KAFFED in Turkey and the International Circassian Association in Russia several main problems of their consolidation can be revealed: 1) the problem of compatriots repatriation during the last nine years (this question mostly concerns refugees from Syria); 2) coolness of Russian-Turkish relationships that influenced the dynamic of Circassians associations cooperation; 3) competition among Circassians organi- 
zations for leadership and the opportunity to portray themselves as the center of ethnic revival.

Hence, the problem of the divided ethnic groups can bring the political instability in the North Caucasus of the Russian Federation. Though the Russian Circassians declared support to federal government policy, the baffling complexity of the situation is the impossibility to solve it in favor of the divided ethnos without violating the territorial integrity principle. Anyway, the oblivion of the divided societies phenomenon by the multiethnic states which have faced this problem nowadays is a considerable neglect. Besides, this question is of great theoretical significance as it demonstrates the controversy of two important trends of the present world globalization and fragmentation on ethnopolitical basis.

Addresses:

Tatiana Nikolaevna Litvinova

Regional Governance and National Politics Department

Moscow State Institute of International Relations

Odintsovo Campus

Novo-Sportivnaya ul. 3

143000 Odintsovo, Russia

E-mail: tantin@mail.ru

Tel. +79161452548

David Gurgenovich Bdoyan

Regional Governance and National Politics Department

Moscow State Institute of International Relations

Odintsovo Campus

Novo-Sportivnaya ul. 3

143000 Odintsovo, Russia

E-mail: d.g.bdoyan@gmail.com

\section{References}

Akkieva, Svetlana I. and Èl’berd M. Kocev (2016) "Voprosy repatriacii adygov (čerkesov) na istoričeskuju rodinu: sostojanie i problemy”. [Issues of repatriation of Adyghes (Circassians) to their historical homeland: the current state and problems.] "White Spots" of the Russian and World History 6, 9-21. Available online at $<$ http://publishing-vak.ru/file/archive-history-20166/1-akkieva-kotsev.pdf $>$. Accessed 20.06.2021.

Alankuş, Sevda and Erol Taymaz "The formation of a Circassian diaspora in Turkey". Adyghe (Cherkess) in the 19th century: problems of war and peace. Maikop: Maikop State Technology University.

Bashqawi, Adel (2019) The Circassian miracle: the nation neither tsars, nor commissars, nor Russia could stop. US: Xlibris Corp. 
Brecher, Jeremy, John Brown Childs, and Jill Cutler, eds. (1993) Global visions: beyond the new world order. Boston: South End Press.

Bredixin A. V. (2019) "Puti razrešenija ‘čerkesskogo voprosa' na juge Rossii (na primere XXII Zimnix Olimpiyskix igr v Soči)". [Ways to resolve the 'Circassian issue' in the south of Russia (on the example of the XXII Winter Olympic Games in Sochi).] Arxont 2, 11, 31-37.

Caya, Sinan (2015) "Relations among various ethnicities in today's modern Turkey". Procedia - Social and Behavioral Sciences 190, 299-304. DOI: 10.1016/j.sbspro.2015.05.002

Cibenko, Veronika V. (2019) “Učastiye etničeskix men'šinstv v političeskoy transformacii Turcii: primer čerkesskoy diaspory". [Participation of ethnic minorities in Turkey's political transformation: an example of the Circassian diaspora.] Proceedings of the Institute of Oriental Studies of RAS $20,56-66$.

Clifford, James (1994) “Diasporas”. Cultural Anthropology 9, 3, 302-338. DOI: https://doi.org/10.1525/ can.1994.9.3.02a00040

Čočiev, Georgij V. (2013) “Peticija čerkesskoj znati Porte (okolo 1872 g.)”. [Petition of the Circassian nobility to the Porte (circa 1872).] Vostok (ORIENS) 2, 124-141.

Dogan, Aysenur (2019) “Osmanlı devleti'nde Çerkes muhacirlerin eğitim faaliyetleri ve Ğuaze gazetesinde eğitime dair yazılar”. VAKANÜVIS- Uluslararası Tarih Araştırmaları Dergisi. International Journal of Historical Researches 4, 1, 142-165.

Esman, Milton J. (1994) Ethnic politics. Ithaca, NY: Cornell University Press.

Federation of Caucasian Associations (2015) "Kaffed meets with the Russian ambassador". Available online at <http://www.kaffed.org/en/news-and-events/item/2830-kaffed-meets-with-therussian-ambassador.html>. Accessed 20.06.2021.

Federation of Caucasian Associations (2020) "21 May". Available online at <http://www.21mayis.org/ index.php/en/research/21-may.html>. Accessed 20.06.2021.

Gafarli, Orkhan (2014) "The role of North Caucasus diaspora groups in Turkey-Russian relations". Turkish Policy Quarterly 13, 1, 172-182.

Gellner, Ernst (1983) Nations and nationalism. Ithaca, NY: Cornell University Press.

Goker, Eylem Akdeniz (2018) “'Nereye aitiz?’ Diasporik kimlik ve Türk vatandaşliği kuskacinda Çerkes kimliği”. ['Where do we belong?' Diasporic identity and Turkish citizenship skeptically Circassian identity.] Sosyal Bilimler Dergisi. Journal of Social Sciences, 3, 1, 91-105.

Grebennikov, Marat (2015) "How far is too far? Circassian ethnic mobilization and the redrawing of internal borders in the North Caucasus". Communist and Post-Communist Studies 48, 1, 71-81. DOI: https://doi.org/10.1016/j.postcomstud.2015.01.003

Gricevič, Anna (2021) “Čerkesskiye aktivisty vozmuščeny otmenoy šestvija v den' pamjati i skorbi v Maykope". [Circassian activists are outraged by the cancellation of the march on the Day of Memory and Mourning in Maykop.] Caucasian Knot, May 22. Available online at $<\mathrm{https}: / /$ www.kavkaz-uzel.eu/articles/364152/>. Accessed 08.07.2021.

Güsar, Vasfi (1975) "Çerkez Kadınları Teavün Cemiyeti”. [Circassian Women Teavun Association.] Kafkasya Dergisi 48, 21-26.

Hansen, Lars F. (2012) "Renewed Circassian mobilization in the North Caucasus. 20-years after the fall of the Soviet Union". Journal on Ethnopolitics and Minority Issues in Europe: JEMIE 11, 2, 103-135.

International Circassian Association (1991) "Charter of International Circassian Association”. 20 May. Available online at $<\mathrm{http}: / /$ intercircass.org/>. Accessed 20.06.2021. 
International Circassian Association (2009) "VIII Congress of the International Circassian Association". Available online at $<\mathrm{http}: / / \mathrm{mcha} . \mathrm{kbsu} . \mathrm{ru} / \mathrm{m}$ ispolkom28.htm $>$. Accessed 20.06.2021.

International Circassian Association (2014) "Protocol No. 1 of the meeting of the Council of the International Circassian Association". 29 November. Available online at $<$ http://intercircass. $\operatorname{org} / \mathrm{p}=5536>$. Accessed 20.06.2021.

International Circassian Association (2020) News. May 13, 19, 21, 30. Available online at $<\mathrm{http} / /$ intercircass.org/?cat=3>. Accessed 20.06.2021.

KAFFED (2015) "Rusya'nın Ankara Büyükelçisi İle Görüştü”. 08 Aralık. [KAFFED met with the Russian Ambassador to Ankara. 8 December.] KAFFED. Available online at $<$ https://www. kaffed.org/haberler/federasyondan/item/2819-kaffed,-rusya'nın-ankara-büyükelçisi-ilegörüştü.html>. Accessed 20.06.2021.

KAFFED (2021) "KAFFED'in Kabardey Balkar Cumhuriyeti ziyareti”. 08 Temmuz [KAFFED's visit to the Kabardino-Balkarian Republic". July 08.] KAFFED. Available online at $<\mathrm{https} / /$ www. kaffed.org/haberler/federasyondan/item/4421-kaffedin-kabardey-balkar-cumhuriyeti-ziyareti. html>. Accessed 08.07.2021.

Kaya, Ayhan (2005) "Circassian diaspora in Turkey: stereotypes, prejudice and ethnic relations". In Nedret Kuran-Burçoğlu and S. G. Miller, eds. Representations of the others in the mediterranean world and their impact on the region, 217-240. Istanbul: The ISIS Press.

Krasnopol'skaja Irina and Galina Solodova (2016) “Perepis' naselenija kak instrument stroitel'stva nacij". [National Census as an instrument of nation building in the postindustrial age.] Mir Rossii 25, 1, 55-78.

Maratova, Ludmila (2019) “Miting pamjati žertv Kavkazskoy voyny sobral v Nal'čike 3000 čelovek”. [A rally in memory of the victims of the Caucasian war gathered 3,000 people in Nalchik]. Caucasian Knot. 22 May. Available online at <https://www.kavkaz-uzel.eu/articles/335725/>. Accessed 20.06.2021.

O'Leary, Brendan (2007) “Analysing partition: definition, classification and explanation”. Political Geography 26, 8, 886-908. DOI: https://doi.org/10.1016/j.polgeo.2007.09.005

Oral, Mustafa (2008) “Sultan ii. Abdülhamit döneminde bir “Çerkes tarihi” yazilmasi girişimi”. [Sultan II. An Attempt to Write a "Circassian history" in the Period of Abdul Hamid.] ÇTTAD VII/16-17, (2008/Bahar-Güz), 71-88.

REGNUM (2009) "Čerkesy ob'edinjaucja, no ne so vsemy". [Circassians unite, but not with all.] Maykop, 21 July. Available online at <https://regnum.ru/news/1188400.html $>$. Accessed 20.06.2021.

Safran, William (1991) "Diasporas in modern societies: myths of homeland and return". Diaspora: A Journal of Transnational Studies 1, 1, 83-99. DOI: 10.1353/dsp.1991.0004

Smith, Anthony (1993) "The ethnic sources of nationalism". Survival 35, 1, 48-62. DOI: https://doi. org/10.1080/00396339308442673

Soveckaja Adygeja (2002) "V celjah konsolidacii”. [In order to consolidate.] 24, 26 September.

Tsibenko, Veronika V. and Sergey N. Tsibenko (2015) "Circassian question: transformation of content and perception". Bylye Gody 36, 2, 450-460.

Tsibenko, Veronoka V. (2016) "Circassian ethnic mobilization as a factor of contemporary RussianTurkish relations". In Tayyar Ari and Bariş Özdal, eds. VII. ULUDA $\breve{G}$ Conference on International relations - In search of a new order in international system (21-22 October, 2015, Bursa), 440-458. Bursa: Dora. 
Tuayev, Magomed (2019) “Istanbul authorities ban Circassians' march to Russia's Consulate General”. Caucasian Knot. 22 May. Available online at <https://www.eng.kavkaz-uzel.eu/ articles/47245/>. Accessed 20.06.2021.

Uznarodov, Dmitry (2016) "The Cherkessk issue in the South Russia: inner challenges and geopolitical risks". Science Almanac of Black Sea Region Countries 3, 7, 57-64.

Uznarodov, Dmitry (2019) “Čerkesskij vopros na juge Rossii: ètnopolitičeskie itogi i perspektivy”. [Circassian issue in the south of Russia: ethnopolitical outcomes and prospects.]. Kavkazologija / Caucasology 3, 222-239. DOI: https://doi.org/10.31143/2542-212X-2019-3-222-239

Vserossijskaja perepis'naselenija. [All-Russian population census.] (2010) Tom 4. Nacional'nyj sostav i vladenie jazykami, graždanstvo. [Vol. 4: Ethnic composition and language skills, citizenship.] Available online at <https://rosstat.gov.ru/free_doc/new_site/perepis2010/croc/perepis itogi1612.htm>. Accessed 20.06.2021.

Zhemukhov, Sufian (2008) "Circassian world responses to the new challenges". PONARS Eurasia Policy Memo 54, 1-7.

Zhemukhov, Sufian (2012) "The birth of modern Circassian nationalism". Nationalities Papers 40, 4, 503-524. DOI: https://doi.org/10.1080/00905992.2012.674019 